\title{
Quality characteristics of spray dried powder from unripe fig extract
}

\author{
Ho-Yong Chae, Joo-Heon Hong* \\ Department of Food Science and Technology, Catholic University of Daegu, Gyeongsan 38430, Korea
}

\section{미숙 무화과 추출물을 이용한 분무건조 분말의 품질특성}

\author{
채호용 - 홍주헌* \\ 대구가톨릭대학교 식품공학전공
}

\begin{abstract}
In this study, the quality characteristics of spray dried powders from unripe fig extract were investigated. The protease activities of unripe fig and peeled unripe fig extract were $0.11 \mathrm{unit} / \mathrm{mL}$ and $0.28 \mathrm{unit} / \mathrm{mL}$, respectively. The spray dried powder of unripe fig extracts was analzed using different maltodextrin ratios (F-MD 5, 5\% maltodextrin; F-MD 10, 10\% maltodextrin; and F-MD 20, 20\% maltodextrin). The spray-dried powder showed the highest protease activity with F-MD $10(0.84 \mathrm{unit} / \mathrm{g})$. The moisture content and $L$ value of the spray-dried powder were higher than those of the freeze-dried powder. The particle diameter of the freeze-dried powder $(209.67 \mu \mathrm{m})$ was higher than that of the spray-dried powders $(22.18 \sim 37.33 \mu \mathrm{m})$. The water absorption index ranged from 0.18 to 0.40 , while the water solubility index ranged from $94.40 \%$ to $98.80 \%$. In the in vitro digestion study, spray-dried powders of the unripe fig showed a protease survival range of $16.47 \% \sim 24.80 \%$. In conclusion, it is considered appropriate to use the spray-dried powder (F-MD 10) of unripe fig as a meat tenderizer for processing food.
\end{abstract}

Key words : unripe fig, protease activity, spray drying, quality characteristics

\section{서 론}

무화과(Ficus carica L.)는 아열 대성 반교목성 낙엽활엽 수로 뽕나무과(Moraceae)에 속하는 식물로 세계적으로 600 여종 이상의 품종이 분포하고, 오랜 역사상 인간이 가장 먼저 이용한 과일로 알려져 있다(1). 또한 무화과는 병충해 가 적고 재배가 용이한 다수확성 과수로 비타민, 미네랄, 단백질 분해효소인 ficin을 다량 함유하고 있어 소화촉진 및 주독이나 어독에 효과가 있어 예부터 서양에서는 건강식 으로 소비되고 있으며 $(2,3)$ ficin은 ficus속 나무에서 발견할 수 있는 효소로서 bromelain, papain 및 그 밖의 protease들과 같이 연육효소로 이용될 수 있다(4). 원산지는 소아시아의 카리카(carica)지방이며(5) 오늘날 세계적인 주요 산지는 미

*Corresponding author. E-mail : jhhong@cu.ac.kr

Phone : 82-53-850-3218; Fax : 82-53-850-3218

Received 9 March 2016; Revised 29 March 2016; Accepted 7 April 2016.

Copyright (c) The Korean Society of Food Preservation. All rights reserved.
국의 캘리포니아와 지중해 부근으로 비교적 비가 많고 배수 가 잘 되는 지역에서 재배되고 있다(6). 우리나라의 주 생산 품종은 보통계 품종인 봉래시(horaish)와 승정도후인(masui dauphine)으로 생식용 과실로서 9월에서 10월까지 수확되 는 가을 과일로 재배되고 있다(7). 한편, 무화과는 생과로서 저장성이 매우 불량하여 수확 즉시 적절한 저장 또는 가공 처리를 하지 않으면 과실로서의 가치가 떨어져 고소득 과수 로서 가능성이 높으나 각광을 받지 못하는 실정이다(8) 또한 우리나라에서는 노지재배가 대부분을 차지하고 있어 수확기의 많은 강우량 및 수년마다 한 번씩 찾아오는 한파 에 안정적인 재배가 어려우며(9) 기상상황 및 8월 초순 이후 적심하게 되면 적심부위가 10 월 말경 서리를 맞아 미성숙 무화과는 성숙이 정지된 채로 수확을 마무리하게 된다(10). 이러한 미숙 무화과는 상품과로서의 가치가 없어 폐기되고 있다. 현재 무화과를 이용한 연구에는 식중독균에 대한 항 균활성(11), 국내산 무화과의 이화학적 특성 및 항산화 활성 (12), 무화과를 이용한 속성발효 멸치액젓에 관한 연구(13) 및 반응표면분석법에 의한 무화과 열수 추출조건의 최적화 (14) 등 다양한 연구가 이루어지고 있지만 이는 완숙한 무화 
과를 이용한 연구들로 미숙 무화과에 관한 연구는 전무한 실정이다.

미세캡슐화의 기술은 불안정한 물질을 외부환경, 즉 빛, 산소 및 수분으로부터 보호하여 손실을 줄이고 반응성이 큰 물질을 격리시키고 냄새, 맛을 은폐시키며 고형화시켜 취급을 간편하게 하고, 내용물의 용출속도를 조절하는 등 의 목적으로 이용되고 있다 $(15,16)$. 그중 분무건조법(spray drying)은 피복물질을 수화시킨 후, 대상물질에 분산시키고 이 혼합물을 고온의 chamber로 분무하는 방법으로(17) 상 업화된 방법 중 가장 보편화 된 것으로 그 생산량도 가장 많아 여러 분야에서 다양한 목적으로 이용되고 있다 (18-20). 분무건조법의 장점은 비용이 저렴하며 최종산물의 안정성이 좋고 대량으로 계속적인 생산이 가능하여(21) 다 른 건조방식에 비해 용해성, 유동성이 좋은 구상 분말 제품 을 제조할 수 있다(22).

이에 본 연구에서는 상품성이 없고 식용으로 이용할 수 없어 전량 폐기가 되고 있는 미숙 무화과를 분무건조 공정 을 이용하여 분말로 제조하였고 분말의 품질특성을 분석하 여 향후 식품 가공용 육류 연화제로서의 개발 가능성을 확인하고자 하였다.

\section{재료 및 방법}

\section{실험재료}

본 실험에 사용된 미숙 무화과(Ficus carica L.)는 경상북 도 고령군의 산솔농장에서 재배된 것을 제공받아 사용하 였다.

미숙 무화과 추출물의 제조

미숙 무화과 추출물은 껍질을 박피하고 가식부분을 잘게 썬 후 미숙 무화과 가식부와 증류수를 1:3 (w/v)의 비율로 혼합한 다음 분쇄기(problend 6, Philips, Amsterdam, Netherlands)로 10 분간 분쇄하였고, 이를 원심분리기 (1236MG, GYROZEN Co., Ltd., Daejeon, Korea)를 이용하 여 $3,000 \mathrm{rpm}$ 에서 10 분간 원심분리 한 후 상등액을 감압여 과하여 제조하였다.

\section{분무건조 분말 제조}

미숙 무화과 추출물 $400 \mathrm{~mL}$ 에 maltodextrin(maltodextrin, Baolingbao biology Co., Ltd., Shandong, China)을 $5 \%, 10 \%$ 및 $20 \%$ 비율로 첨가 후 homogenizer(HG-15D, DAIHAN scientific Co., Ltd., Wonju, Korea)로 7,000 rpm에 서 10 분간 균질화하여 분무건조용 시료로 제조하였다. 분 무건조 조건은 분무건조기(KL-8, Seogang engineering Co., Ltd., Cheonan, Korea)를 이용하여 주입 온도 $150^{\circ} \mathrm{C}$, 방출 온도 $100^{\circ} \mathrm{C}$, 시료 공급속도는 $12 \mathrm{~mL} / \mathrm{min}$ 으로 하였으며
$17,000 \mathrm{rpm}$ 으로 atomizer를 작동하여 분무건조 후 분말을 $-70^{\circ} \mathrm{C}$ 이하의 암소에 보관하면서 시료로 이용하였다. 대조 실험구는 부형제를 첨가하지 않은 동결건조분말을 사용하 여 비교하였다.

\section{Protease 활성 측정}

Protease 활성은 Kunitz법(23)을 변형하여 측정하였다. $0.2 \mathrm{M}$ sodium phosphate buffer(pH 7.0) $0.5 \mathrm{~mL}$ 에 시료 0.5 $\mathrm{mL}$ 를 혼합하고 $0.6 \%$ casein 용액(w/v, Duksan pure chemicals Co., Ltd., Ansan, Korea) $0.5 \mathrm{~mL}$ 를 가하여 진탕항 온수조(BS-31, Jeio tech Co., Ltd., Seoul, Korea)를 이용하여 $37^{\circ} \mathrm{C}, 100 \mathrm{mpm}$ 에서 20 분간 반응시킨 후 $0.44 \mathrm{M}$ trichloroacetic $\operatorname{acid(Acros~organics,~NJ,~USA)~} 2.0 \mathrm{~mL}$ 를 첨가, 원심분리기 (1236MG, GYROZEN Co., Ltd., Daejeon, Korea)를 이용하 여 $3,000 \mathrm{rpm}$ 에서 10 분간 원심분리 하였다. 상등액 $1.5 \mathrm{~mL}$ 에 $0.55 \mathrm{M}$ sodium carbonate anhydrous(Duksan pure chemicals Co., Ltd., Ansan, Korea) $1.0 \mathrm{~mL}$ 와 $1 \mathrm{~N}$ Folin ciocalteu 용액(Sigma-Aldrich Co., St. Louis, MO, USA) 1.0 $\mathrm{mL}$ 를 가하고 $37^{\circ} \mathrm{C}$ 에서 30 분간 발색반응시킨 다음 분광광도 계(Ultraspec- 2100pro, Amersham Co., Uppsala, Sweden)를 이용하여 $660 \mathrm{~nm}$ 에서 흡광도를 측정하였다. Protease 활성 은 tyrosine (Sigma-Aldrich Co., St. Louis, MO, USA)을 정량 하여 작성한 표준곡선으로부터 계산하였으며, 활성단위 (unit)는 1 분당 $1 \mu \mathrm{g}$ 의 tyrosine을 생성하는 효소의 양으로 정의하였다.

\section{수분함량, 색도 및 입자크기 측정}

분말의 수분함량은 적외선 수분측정기(MB-45, Moisture analyzer, INC., Ohaus, NJ, USA)를 이용하여 분석하였으며 용기를 항량이 될 때까지 건조한 다음 시료 $0.5 \mathrm{~g}$ 을 $105^{\circ} \mathrm{C}$ 의 온도에서 측정하였다. 색도는 표준색도 $\mathrm{Y}=86.6, \mathrm{x}=0.3160$, $\mathrm{y}=0.3214$ 로 보정된 chromameter(CR-400, Minolta Co., Osaka, Japan)를 이용하여 측정하였으며 L값(brightness), a 값(redness-greenness), $\mathrm{b}$ 값(yellowness-blueness)을 3회 반복 측정하여 평균치로 나타내었다. 부형제에 따른 분말의 입 자크기를 분석하기위해 particle size analyzer(LS-13-320, Beckman coulter, Fullerton, CA, USA)를 이용하여 isopropyl alcohol에 분산시켜 측정하였다.

\section{수분흡수지수 (WAI) 및 수분용해지수(WSI) 측정}

수분흡수지수(water absorption index, WAI) 및 수분용해 지수(water solubility index, WSI) 측정은 philips(24)의 방법 을 변형하여 측정하였다. 분무건조 분말 $0.5 \mathrm{~g}$ 에 $20 \mathrm{~mL}$ 증류수를 첨가하여 $3,000 \mathrm{rpm}$ 에서 20 분간 원심분리한 후 침전물은 수분흡수지수로 사용하였으며, 상등액은 미리 무 게를 구한 수기에 분리하여 dry oven $(\mathrm{OF}-22 \mathrm{GW}$, Jeio tech Co., Ltd., Seoul, Korea)을 이용하여 $100^{\circ} \mathrm{C}$ 에서 5시간 동안 
건조시킨 고형분을 수분용해지수로 사용하여 아래의 식으 로 계산하였다.

$$
\begin{gathered}
\text { 분흡수지수 } \mathrm{WAI})=\begin{array}{c}
\text { 침전물의 양 } \\
\text { 시료량 }
\end{array} \\
\text { 수분용해지수 }(\mathrm{WSI}, \%)=\begin{array}{c}
\text { 상등액의 고형분량 } \\
\text { 시료량 }
\end{array}
\end{gathered}
$$

\section{in vitro 인체 내 소화 모델}

in vitro 인체 내 소화모델에 대한 미숙 무화과의 protease 활성은 Hur 등(25)의 in vitro human digestion의 multi-step model을 변형하여 이용하였으며, 대한약전에 따라 인공 위 액 $(\mathrm{pH} 1.2)$ 은 $0.1 \mathrm{~N}$ hydrochloric acid을, 인공 소장액 $(\mathrm{pH}$ 6.8) 및 인공 대장액 $(\mathrm{pH}$ 7.4)은 $0.1 \mathrm{M}$ sodium phosphate 완충 용액을 사용하여 제조하였다. 시료 $3 \mathrm{~g}$ 에 인공 위액 $10 \mathrm{~mL}$ 를 첨가하여 shaking water bath에서 2시간 반응 후, 인공 소장액 $17 \mathrm{~mL}$ 를 첨가하여 $37^{\circ} \mathrm{C}, 100 \mathrm{mpm}$ 에서 1 시간 반응하 였다. 각 용액 첨가시 sodium bicabonate 및 sodium hydroxide를 사용하여 $\mathrm{pH}$ 를 보정한 다음 $\mathrm{pH} 1.2$ 에서는 1 시 간, $\mathrm{pH} 6.8$ 및 $\mathrm{pH}$ 7.4에서는 30 분 간격으로 하여 용출된 protease 활성을 측정하였다.

\section{통계처리}

실험결과는 3회 반복으로 행하여 평균표준편차로 나타 내었고 SPSS(19.0, SPSS INC., Chicago, IL, USA)를 이용하 여 분산분석을 실시하였으며 각 측정 평균값의 유의성 $(\mathrm{p}<0.05)$ 은 Duncan's multiple range test로 검정하였다.

\section{결과 및 고찰}

\section{미숙 무화과 추출물의 protease 활성}

박피 전후에 따른 미숙 무화과 추출물의 protease 활성을 비교하여 Table 1에 나타내었다. 박피 전 미숙 무화과 추출 물의 protease 활성은 $0.11 \mathrm{unit} / \mathrm{mL}$ 이었으며 박피 후 protease 활성은 $0.28 \mathrm{unit} / \mathrm{mL}$ 로 박피 처리된 미숙 무화과의 효소활 성이 더 높은 것을 확인할 수 있었다. Yoo 등(26)에 따르면 일반 무화과의 효소활성은 0.69 unit $/ \mathrm{mL}$ 의 효소활성을 나타 내었다고 하였으나 이는 미숙과와 완숙과의 시료 및 손질법 에 따른 차이로 실제 효소활성은 미숙과와 완숙과 간 큰 차이가 없을 것으로 사료가 된다. 일반적으로 고기의 연화 를 위해 식물에서 추출한 효소인 파파인, 브로멜라인, 피신 을 이용하고 있으며 이들은 시스테인계 단백질분해효소로 콜라겐과 근원섬유 단백질에 강한 활성을 가져 육류 연화효 소로 사용되며(27) 향후 미숙 무화과를 육류 연화제로 이용 을 할 경우 박피를 하여 사용하는 것이 protease활성 측면에 서 효과적일 것으로 판단된다.
Table 1. Protease activity of unripe fig and peeled unripe fig extract

\begin{tabular}{cc}
\hline Samples & Protease activity (unit/mL) \\
\hline Unripe fig extract & $0.11 \pm 0.01^{1)}$ \\
Peeled unripe fig extract & $0.28 \pm 0.01$ \\
\hline
\end{tabular}

${ }^{1)}$ All values are means $\pm \mathrm{SD}(\mathrm{n}=3)$.

\section{분무건조 분말의 protease 활성}

미숙 무화과의 식품 가공용 연육제로의 활용 가능성을 확인하기 위하여 추출물을 분무건조하여 분말화 하였으며 시중에 판매되고 있는 연육제와 비교하여 Table 2에 나타내 었다. 실험의 농도는 $50,000 \mathrm{\mu g} / \mathrm{mL}$ 로 진행하였다. 실험결과 protease 활성은 동결건조 분말이 $0.92 \mathrm{unit} / \mathrm{g}$ 으로 가장 높은 활성을 나타내었으며 분무건조 분말 중 maltodextrin $10 \%$ 첨가구가 $0.84 \mathrm{unit} / \mathrm{g}$ 으로 효소활성이 가장 높았다. maltodextrin $5 \%$ 와 $20 \%$ 첨가구 및 시중 육류 연화제는 각각 $0.48 \mathrm{unit} / \mathrm{g}, 0.50 \mathrm{unit} / \mathrm{g}$ 및 $0.11 \mathrm{unit} / \mathrm{g}$ 으로 효소활성이 낮았다. Park 등(28)의 분무건조 공정을 이용한 파인애플 실험에서 파인애플 착즙액 동결건조 분말의 효소활성이 분무건조 분말보다 높아 본 실험과 유사한 실험결과를 나타 내었다. Kim 등(29)의 연구에서는 효소식품을 동결건조하 는 경우 장시간 건조 및 보관에 따른 효소 실활이 일어날 수 있다고 보고하여 식품가공용 연육제로 이용 시 동결건조 법 보다 분무건조법을 이용하고 부형제로는 maltodextrin을 $10 \%$ 비율로 첨가하는 것이 가장 좋은 구간으로 사료된다.

Table 2. Protease activity of spray-dried powders from unripe fig extract

\begin{tabular}{cc}
\hline Samples $^{1)}$ & Protease activity (unit/g) \\
\hline F-MD 5 & $0.48 \pm 0.07^{\mathrm{c} 2)}$ \\
F-MD 10 & $0.84 \pm 0.04^{\mathrm{b}}$ \\
F-MD 20 & $0.50 \pm 0.01^{\mathrm{c}}$ \\
F-FD & $0.92 \pm 0.05^{\mathrm{a}}$ \\
MT & $0.11 \pm 0.01^{\mathrm{d}}$ \\
\hline
\end{tabular}

${ }^{1)} \mathrm{F}-\mathrm{MD} 5$, spray-dried powder with $5 \%$ maltodextrin; F-MD 10, spray-dried powder with $10 \%$ maltodextrin; F-MD 20, spray-dried powder with $20 \%$ maltodextrin; F-FD, freeze-dried powder from unripe fig extract; MT, meat tenderizer.

${ }^{2)}$ All values are mean $\pm \mathrm{SD}(\mathrm{n}=3)$. Means with different superscript $(\mathrm{a}-\mathrm{d})$ in the same column are significantly different at $\mathrm{p} 0.05$.

\section{수분함량, 색도 및 입자크기}

분무건조 분말의 수분함량, 색도 및 입자크기는 Table 3 과 같다. 수분함량은 동결건조 분말에서 $1.47 \%$ 로 가장 낮은 것을 확인할 수 있었으며 분무건조 분말은 2.59 2.65\% 로 부형제의 첨가량이 증가할수록 수분함량이 증가하는 경향이었다. Lee 등(30)의 백미 발효물의 분무건조 분말이 $2.90 ~ 3.83 \%$ 의 수분함량과 동결건조 분말이 $2.30 \%$ 로 가장 낮은 수분함량을 나타내었다고 보고하였으며 Park 등(31) 
유산균포집 분무건조 분말이 2.32 3.34\%의 수분함량으로 본 연구결과와 유사한 수분함량을 나타내었다. 색도는 분 무건조 분말이 동결건조 분말보다 $\mathrm{L}$ 값이 높고 $\mathrm{b}$ 값이 낮아 더 선명한 황색을 보여주었으며 부형제인 maltodextrin 첨 가량이 증가할수록 L값은 80.31 86.22까지 증가하고 a값 및 b값은 각각 8.91 5.66, 4.79 4.18로 각각 낮아지는 경향 을 나타내었다. Maltodextrin 5\%,10\%, 20\% 및 동결건조 분말의 입자크기는 각각 $22.18 \mu \mathrm{m}, 26.58 \mu \mathrm{m}, 37.33 \mu \mathrm{m}$ 및 $209.67 \mu \mathrm{m}$ 로 부형제의 첨가량이 증가할수록 입자의 크 기가 증가하는 경향을 보였다. Kang 등(32)의 연구에 따르 면 일반적으로 미세캡슐 분말의 입자 크기는 1 200 $\mu \mathrm{m}$ 의 범위에 분포한다고 하였으며 Rosenberg 등(33)은 입자크기 가 작을수록 내부 물질을 포접하는데 유리하다고 한 연구결 과에 따라 미숙 무화과 유래 분무건조 분말이 동결건조 분말에 비해 안정성이 더 향상되었을 것으로 사료가 된다.

Table 3. Moisture, color value and particle diameter of spray-dried powders from unripe fig extract

\begin{tabular}{cccccc}
\hline \multirow{2}{*}{ Samples $^{1)}$} & $\begin{array}{c}\text { Moisture } \\
(\%)\end{array}$ & \multicolumn{3}{c}{ Hunter's color values } & Particle \\
\cline { 3 - 5 } & & $\mathrm{L}$ & $\mathrm{a}$ & $\mathrm{b}$ & $\begin{array}{c}\text { diameter } \\
(\mu \mathrm{m})\end{array}$ \\
\hline F-MD 5 & $2.59 \pm 0.01^{\mathrm{b} 2)}$ & $80.31 \pm 0.02^{\mathrm{c}}$ & $8.91 \pm 0.01^{\mathrm{a}}$ & $4.79 \pm 0.01^{\mathrm{b}}$ & $22.18 \pm 0.32^{\mathrm{d}}$ \\
F-MD 10 & $2.60 \pm 0.01^{\mathrm{b}}$ & $82.68 \pm 0.02^{\mathrm{b}}$ & $7.47 \pm 0.01^{\mathrm{b}}$ & $4.41 \pm 0.01^{\mathrm{c}}$ & $26.58 \pm 0.01^{\mathrm{c}}$ \\
F-MD 20 & $2.65 \pm 0.01^{\mathrm{a}}$ & $86.22 \pm 0.03^{\mathrm{a}}$ & $5.66 \pm 0.01^{\mathrm{c}}$ & $4.18 \pm 0.01^{\mathrm{c}}$ & $37.33 \pm 0.15^{\mathrm{b}}$ \\
F-FD & $1.47 \pm 0.01^{\mathrm{c}}$ & $68.79 \pm 0.63^{\mathrm{d}}$ & $7.57 \pm 0.26^{\mathrm{b}}$ & $11.81 \pm 0.25^{\mathrm{a}}$ & $209.67 \pm 3.29^{\mathrm{a}}$ \\
\hline
\end{tabular}

${ }^{1)} \mathrm{F}-\mathrm{MD} 5$, spray-dried powder with $5 \%$ maltodextrin; F-MD 10, spray-dried powder with $10 \%$ maltodextrin; F-MD 20, spray-dried powder with $20 \%$ maltodextrin; F-FD, freeze-dried powder from unripe fig extract; MT, meat tenderizer.

${ }^{2)}$ All values are mean $\pm S D(n=3)$. Means with different superscript $(a-d)$ in the same column are significantly different at p 0.05 .

\section{수분흡수지수(WAI) 및 수분용해지수(WSI)}

미숙 무화과 분무건조 분말의 수분흡수지수와 수분용해 지수를 Table 4에 나타내었다. 분말의 수분흡수지수 및 수 분용해지수는 식품산업 활용 측면에서 중요한 가공적성 요인으로 알려져 있다(34). 수분흡수지수는 maltodextrin

Table 4. Water absorption index and water solubility index of spray-dried powders from unripe fig extract

\begin{tabular}{ccc}
\hline Samples $^{1)}$ & $\begin{array}{c}\text { Water absorption index } \\
\text { (WAI) }\end{array}$ & $\begin{array}{c}\text { Water solubility index } \\
\text { (WSI, \%) }\end{array}$ \\
\hline F-MD 5 & $0.18 \pm 0.06^{\mathrm{b} 2)}$ & $98.80 \pm 0.04^{\mathrm{a}}$ \\
F-MD 10 & $0.11 \pm 0.01^{\mathrm{b}}$ & $99.10 \pm 0.36^{\mathrm{a}}$ \\
F-MD 20 & $0.23 \pm 0.13^{\mathrm{b}}$ & $98.08 \pm 1.42^{\mathrm{a}}$ \\
F-FD & $0.40 \pm 0.08^{\mathrm{a}}$ & $94.40 \pm 2.12^{\mathrm{b}}$ \\
\hline
\end{tabular}

${ }^{1)}$ F-MD 5, spray-dried powder with 5\% maltodextrin; F-MD 10, spray-dried powder with $10 \%$ maltodextrin; F-MD 20, spray-dried powder with $20 \%$ maltodextrin; F-FD, freeze-dried powder from unripe fig extract; MT, meat tenderizer.

${ }^{2)}$ All values are mean $\pm S D(n=3)$. Means with different superscript $(a-b)$ in the same column are significantly different at $p<0.05$.
$10 \%$ 첨가구가 0.11 로 가장 낮았으며 동결건조 분말이 0.40 으로 가장 높은 수분흡수지수를 나타내었다. 수분용해지수 는 maltodextrin $10 \%$ 첨가구가 $99.10 \%$ 로 가장 높았으며 동 결건조 분말이 $94.40 \%$ 로 가장 낮은 값을 나타내었다. 이에 동결건조 분말보다 유의적으로 용해성이 양호한 분말을 얻을 수 있을 것이라 판단되며 물 결합 능력은 전분 입자내 의 비결정성부분에 의한 것으로 전분입자에 비결정성 부분 이 많을수록 그리고 전분입자의 내부 치밀도가 낮을수록 수분흡수도가 크다고 보고되어(35) 분무건조 분말이 내부 결정을 견고하게 잘 이루어서 수분흡수지수가 낮은 것으로 사료된다.

\section{in vitro 인체 내 소화 모델}

분무건조 분말의 in vitro 인체 내 소화 모델에 따른 protease 활성을 Fig. 1에 나타내었다. 분무건조 분말은 $\mathrm{pH}$ 1.2 의 인공 위액에서 효소활성이 나타나지 않았으며 2.5시 간째인 인공 소장액인 $\mathrm{pH}$ 6.8에서 maltodextrin $10 \%$ 실험구 가 $0.12 \mathrm{unit} / \mathrm{g}$, maltodextrin $20 \%$ 에서 $0.07 \mathrm{unit} / \mathrm{g}$ 의 효소활성 을 나타내었다. maltodextrin 5\% 첨가구는 실험 3시간부터 효소활성을 보였으며 최종적으로 maltodextrin $5 \%, 10 \%$ 및 $20 \%$ 첨가구는 실험 4 시간째인 $\mathrm{pH} 7.4$ 의 인공 대장액에서 각각 $0.08 \mathrm{unit} / \mathrm{g}, 0.21 \mathrm{unit} / \mathrm{g}$ 및 $0.11 \mathrm{unit} / \mathrm{g}$ 의 효소활성을 나타내었다. 동결건조 분말의 경우 모든 구간에서 효소활 성이 나타나지 않았다. Lee (36)의 아마란스 발효물 분무건 조 분말 연구에서 동결건조 분말은 효소의 저장 및 섭취과 정에서 열과 강산, 강알칼리에 불안정하다고 보고하였다. 따라서 동결건조된 미숙 무화과 분말이 인공위액(pH 1.2) 에 의해 효소가 실활 된 것으로 사료되며 분무건조 분말은 이 구간에서 protease 활성을 보여주어 내산성이 있는 것으 로 확인되었다.

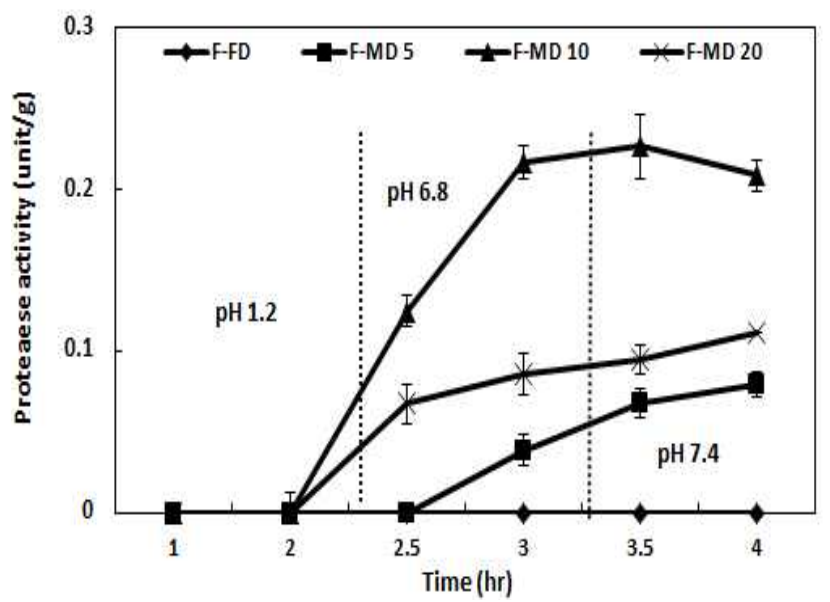

Fig. 1. In vitro dissolution of spray-dried powders from unripe fig extract in simulated $\mathrm{pH} 1.2, \mathrm{pH} 6.8$ and $\mathrm{pH}$ 7.4.

, freeze-dried powder from unripe fig extract; $\square$, spray-dried powder with $5 \%$ maltodextrin; $\boldsymbol{\Lambda}$, spray-dried powder with $10 \%$ maltodextrin; $\times$, spray-dried powder with $20 \%$ maltodextrin. All values are mean \pm SD $(n=3)$. 


\section{요 약}

본 연구에서는 상품과로서 가치가 없어 전량 폐기되고 있는 미숙 무화과를 이용하여 산업적 이용 증대 및 식품 가공용 연육제로의 활용 가능성을 확인하기 위하여 미숙 무화과에 부형제인 maltodextrin을 5\%, $10 \%$ 및 $20 \%$ 를 첨가 하여 혼합한 후 분무건조공정을 이용하여 분말화 하였다. 분무건조 분말의 수분함량은 2.59 2.65\% 였으며 부형제인 maltodextrin 첨가량이 늘어날수록 색도는 $\mathrm{L}$ 값이 늘고 $\mathrm{a}$ 와 $\mathrm{b}$ 값은 줄어드는 경향을 나타내었고 입자크기는 동결건조 분말 $(209.67 \mu \mathrm{m})$ 에 비하여 22.18 37.33 $\mu \mathrm{m}$ 로 유의적으로 작고 균일한 크기였다. 수분흡수지수는 maltodextrin $10 \%$ 첨가군이 0.11 로 가장 낮았으며 수분용해지수는 $99.10 \%$ 로 가장 높았다. 전체적으로는 분무건조 분말이 동결건조 분 말에 비해 수분흡수지수는 낮고 수분용해지수는 높은 경향 을 나타내어 산업적으로 이용시 분무건조 분말이 동결건조 분말보다 우수할 것으로 사료된다. 미숙 무화과 분말의 protease 활성은 동결건조 분말(0.92 unit/g)이 분무건조 분 말(0.48 0.84 unit/g)보다 유의적으로 높은 활성을 나타내었 으나, in vitro 인체 내 소화 모델에 대한 protease 활성은 분무건조 분말에서만 효소 활성이 나타나 낮은 $\mathrm{pH}$ 에서도 안정함을 확인하였다. 따라서 본 실험결과, 미숙 무화과 분말 제조시 동결건조보다는 maltodextrin을 $10 \%$ 혼합하여 제조된 분무건조 분말에서 protease활성이 우수하였으며 향후식품가공용 연육제로서 활용이 가능할 것으로 판단되 었다.

\section{감사의 글}

본 연구는 교육부와 한국연구재단의 지역혁신창의인력 양성사업으로 수행된 연구결과임(No.2013H1B8A2032215)

\section{References}

1. Williams DC, Sgarbieri VC, Whitaker JR (1968) Proteolytic activity in the genus ficus. Plant Physiol, 43, 1083-1088

2. Kim KH (1981) Chemical components of Korean figs and its storage stability. Korean J Food Sci Technol, 13, 165-169

3. Sgarbieri VC, Gupte SM, Kramer DE, Whitaker JR (1963) Ficus enzymes: I. Separation of the proteolytic enzymes of Ficus carica and Ficus glabrata latices. J Biol Chem, 239, 2170-2177

4. Noh BS, Park KH (1980) Heat inactivation of proteolytic enzymes in papaya latex. Korean J Food Sci Technol, 12, 209-215

5. Vinson JA (1999) The functional food properties of figs. Cereal Foods World, 44, 82-87

6. Kim SS, Lee CH, Oh SL, Chung DH (1992) Chemical components in the two cultivars of Korean figs (Ficus carica L.). J Korean Agric Chem, 35, 51-54

7. Lee KY (1978) pomology particulars. Hyangmunsa, Seoul, Korea, p 500-508

8. Kim DH (1999) Studies on the production of vinegar from fig. J Korean Soc Food Sci Nutr, 28, 53-60

9. Kim HR (2013) Studies on breeding and soil nutrientwater management technology in loquat and common fig. Final Report of NIHHS, NIHHS PJ007482

10. Bang GP (2008) Studies on protected cultivation for environmentally-friendly fig production. Final Report of JARES, JARES 11-1390000-001938-01

11. Jeong MR, Cha JD, Lee YE (2005) Antibacterial activity of Korean fig (Ficus carica L.) against food poisoning bacteria. Korean J Food Cook Sci, 21, 84-93

12. Jeong MR, Kim BS, Lee YE (2002) Physicochemical characteristics and antioxidative effects of Korean figs. J East Asian Soc Dietary Life, 12, 566-573

13. Kang SG, Yoon SW, Kim JM, Kim SJ, Jung ST (2001) Quality of accelerated salt-fermented anchovy sauce prepared with fig. J Korean Soc Food Sci Nutr, 30, 1142-1146

14. Kim JO, Kwon ST, Lee GD, Hong JH, Moon DH, Kim TW, Kim DI (2008) Optimization of extraction condition on fig (Ficus carica L.) by response surface methodology. Korean J Food Preserv, 15, 66-73

15. Tan LH, Chan LW, Heng PWS (2005) Effect of oil loading on microspheres produced by spray drying. J Microencapsul, 22, 253-259

16. Reineccius GA (1991) Carbohydrates for flavor encapsulation. Food Technol, 45, 144-150

17. Cho YH, Shin DS, Park JY (1997) Microencapsulation technology in the food industry. Food Sci Ind, 30, 98-111

18. Hogan SA, McNamee BF, O'Riordan ED, O'Sullivan $M$ (2001) Emulsification and microencapsulation properties of sodium caseinate/carbohydrate blends. Int Dairy J, 11, 137-144

19. Cai YZ, Corke H (2000) Production and properties of spray-dried amaranthus betacyanin pigments. J Food Sci, 65, 1248-1252

20. Han MW, Youn KS (2009) Quality characteristics of spray drying microparticulated calcium after wet-grinding. 
Korean J Food Sci Technol, 41, 657-661

21. Kim EHJ, Chen XD, Pearce D (2005) Melting characteristics of fat present on the surface of industrial spray-dried dairy powders. Colloids Surf Biointerfaces, 42, $1-8$

22. Sano Y (1993) Gas flow behavior in spray dryer. Dry Technol, 11, 697-718

23. Kunitz M (1947) Crystalline soybean trypsin inhibitor: II. general properties. J Gen Physiol, 30, 291-310

24. Phillips RD, Chinnan MS, Granch AL, Miller J, Mcwatters KH (1988) Effects of pretreatment on functional and nutritional properties of cowpea meal. J Food Sci, 53, 805-809

25. Hur SJ, Lee SK, Kim YC, Choi JW (2012) Development of in vitro human digestion models for health functional food research. Food Sci Ind, 45, 40-49

26. Yoo SA, Seo SH, Hyun SY, Son HS (2013) Characteristics of crude protease from fruits and traditional Korean fermentation starters. J Korean Soc Food Sci Nutr, 42, 1461-1466

27. Jang PS, Noh BS, Yoo SH, Kim YW (2010) food enzyme technology. Soohaksa, Seoul, Korea, p 323-355

28. Park HM, Chae HY, Hong JH (2015) Physicochemical properties and protease activities of microencapsulated pineapple juice powders by spray drying process. Korean J Food Preserv, 22, 84-90

29. Kim SS, Kim SY, Lee WJ (1998) Microwave vacuum drying of germinated brown rice as a potential raw material for enzyme food. Korean J Food Sci Technol, 30, 1107-1113

30. Lee DH, Park HM, Hong JH (2015) Physicochemical properties and microencapsulation process of rice fermented with Bacillus subtilis CBD2. Korean J Food Preserv, 22, 225-231

31. Park HM, Lee DH, Jeong YS, Jung HK, Cho JG, Hong JH (2015) Physicochemical roperties of spray-dried rice flour with Lactobacillus plantarum CGKW3. Korean J Food Preserv, 22, 392-398

32. Kang YC, Choi KK, Kim KH, Kim HK (2002) Microencapsulation of Aster scaber and Aster glehni by spray drying. Korean J Food Preserv, 9, 212-220

33. Rosenberg M, Kopelman IJ, Talmon Y (1990) Factors affecting retention in spray-drying microencapsulation of volatile materials. J Agric Food Chem, 38, 1288-1294

34. Lee YR, Choi YH, Koh HJ, Kang MY (2001) Quality characteristics of brown rice flakes prepared with giant embryonic rice and normal rice cultivars. Korean J Food Sci Technol, 33, 540-544

35. Beleia A, Varriano-Marston E, Hoseney RC (1980) Characterization of starch from pearl millets. Cereal Chem, 57, 300-303

36. Lee RH (2016) Physicochemical properties and functionalities of spray-dried powder using fermented amaranth. MS Thesis, Catholic University of Daegu, Korea, p 40-53 